\title{
ROLA I ETYKA PRAWNIKA U KARLA NICKERSONA LLEWELLYNA
}

\begin{abstract}
Streszczenie. Poza krótkim wprowadzeniem na temat filozofii prawa, jaką jest amerykański realizm prawny, w pracy zostały przedstawione rola i etyka prawnika w ujęciu Karla Nickersona Llewellyna. Poglądy tego amerykańskiego realisty prawnego opatrzone są komentarzem autora wraz z próbą ich przeniesienia na grunt polski. Przy tym szczególnie osobliwe jest to, iż zgodnie z obowiązującym w Polsce prawem prawnik nie ma możliwości odmowy podjęcia się obrony sprawy, w której słuszność nie wierzy. Prawo każdego człowieka do uczciwego procesu wydaje się tutaj mieć bezwzględne pierwszeństwo nad tym, co adwokatom i radcom prawnym dyktuje sumienie - $\mathrm{i}$ to nawet przy założeniu, że w praktyce będzie się to czasem odbywało kosztem tego, iż poszczególne sprawy, z powodu braku wiary w ich słuszność, będą prowadzone przez pełnomocników procesowych w sposób nie do końca optymalny.
\end{abstract}

Słowa kluczowe: etyka prawnicza, realizm prawniczy, common law, prawo.

\section{WPROWADZENIE}

Karl Nickerson Llewellyn (żył w latach 1893-1962), najbardziej chyba znany jako autor popularnego podręcznika dla studentów prawa pt. The Bramble Bush [po polsku: Jeżynowy krzew] ${ }^{1}$, to bez wątpienia jeden z czołowych przedstawicieli tzw. amerykańskiego realizmu prawnego. Do pozostałych zaliczani są: Jerome Frank, Max Radin, Joseph C. Hutcheson, John C. Gray, Herman Oliphant, Felix S. Cohen i Benjamin N. Cardozo. Kierunek w filozofii prawa, jakim jest realizm prawny w jego amerykańskim wydaniu, na pewno uwydatniał rolę

* Uczelnia Łazarskiego w Warszawie.

${ }^{1}$ Dokładnie - poza licznymi dodrukami - książka ta miała trzy tytuły. Pierwsze wydanie z 1930 r. zatytułowane było: The Bramble Bush. Some Lecture on Law and its Study; drugie z 1951 r.: The Bramble Bush. On Our Law and Its Study; a ostatnie z 2008 r.: The Bramble Bush. The Classic Lectures on the law and Law School.

Odnośnie do zawartości ostatniego z wydań zob. M. Koszowski, Recenzja książki autorstwa Karla Nickersona Llewellyna: „, The Bramble Bush. The Classic Lectures on the law and Law School. With a new Introduction and Notes by Steve Sheppard”, „Studia Iuridica Toruniensia” 2015, t. 17. 
sędziów i wpływ tego, co oni faktycznie czynią, na treść obowiązującego prawa. Chociaż bez zagłębiania się w szczegóły poglądów wyżej wymienionych osób sprowadzanie istoty tego kierunku do tezy, iż prawo jest tym, co robią (bądź zrobią w danej sprawie) sędziowie, stanowi oczywiście - aczkolwiek niestety często spotykane i to nie tylko w polskiej nauce prawa - uproszczenie, by nie powiedzieć jawne wypaczenie założeń amerykańskiego realizmu prawnego. Realizm ten nie miał też za wiele wspólnego z realizmem w filozofii, będąc o wiele bardziej przejawem jakiegoś naturalizmu, a nie realizmu. Ponieważ jednak nie jemu samemu, a roli i etyce prawnika poświęcony jest niniejszy artykuł, definicję i podstawowe tezy tej filozofii prawa pozwolę sobie tu pominąć (nie są one zresztą do końca spójne i poglądy każdego z ww. autorów mają swoją odrębną specyfikę). W zamian za to poczynię jednak dwie uwagi o charakterze wprowadzającym, które zdają się niezbędne do prawidłowego zrozumienia treści niniejszego artykułu.

Po pierwsze, warto mieć na uwadze, iż amerykańscy realiści prawni mieli to do siebie, iż nie bali się swobodnie pisać o tym, o czym myśleli, również wtedy, gdy innym ich poglądy mogły wydawać się nad wyraz dziwaczne czy wręcz wysoce niestosowne. Tak np. niejaki Oliver Wendell Holmes ni stąd ni z owąd w swojej Ścieżce prawa (ang. The Path of the Law) sugerował, jeśli nie twierdził wprost, iż w prawie nie chodzi o to, by dużo zarabiać, bo o wiele ważniejsze jest to, by sprawować rząd dusz (idei) tudzież kontaktować się ze Wszechświatem (Bogiem, Nieskończonością?)². Joseph C. Hutcheson z kolei otwarcie przyznawał się, a nawet chełpił tym, iż jako sędzia rozstrzyga sprawy nie za pomocą, jak ją określał, logomachii, lecz wolnej gry wyobraźni i uczucia $(\text {,hunch' } u \text { ") })^{3}$.

Po drugie, co jest charakterystyczne dla przedstawicieli tego kierunku filozoficzno-prawnego i aż nad wyraz widoczne u Karla Nickersona Llewellyna, to

2 ,To an imagination of any scope the most far-reaching form of power is not money, it is the command of ideas. [...] And happiness, I am sure from having known many successful men, cannot be won simply by being counsel for great corporations and having an income of fifty thousand dollars. An intellect great enough to win the prize needs other food besides success. The remoter and more general aspects of the law are those which give it universal interest. It is through them that you not only become a great master in your calling, but connect your subject with the universe and catch an echo of the infinite, a glimpse of its unfathomable process, a hint of the universal law”. Zob. O. W. Holmes, The Path of the Law, przedruk w: „Boston University Law Review" 1965, no. 45, s. 42.

3 ,While when the case is difficult or involved, and turns upon a hairsbreadth of law or of fact, [...] I after canvassing all the available material at my command, and duly cogitating upon it, give my imagination play, and brooding over the cause, wait for the feeling, the hunch - that intuitive flash of understanding which makes the jump-spark connection between question and decision, and at the point where the path is darkest for the judicial feet, sheds its light along the way". Zob. J. C. Hutcheson, The Judgment Intuitive: The Function of the „Hunch” in Judicial Decision, przedruk w: „South Texas Law Review” 1998, no. 39, s. 893. 
język, jakim się oni posługiwali (coś z niego udzieliło się też niektórym z współczesnych amerykańskich filozofów prawa) ${ }^{4}$. Jest to bowiem język o wiele mniej formalny, a zarazem o wiele bardziej żywy od języka, w jakim formułuje się myśli w polskiej nauce prawa. Pełno w nim kolokwializmów, barwnych porównań, a nawet i wyrażeń par excellace knajackich. Można w nim dostrzec zarówno nastroje i emocje, jak i szczerą nieugiętą pasję, a przez to i coś, co nadaje koloryt i piękno, jakich nigdy nie da nam sformalizowany, pozbawiony uczucia, de facto sztuczny język twierdzeń czy wywodów stricte naukowych/deskryptywnych. Za pomocą takiego zresztą „,uformalizowania” - jak się wydaje - usiłuje się sprowadzić filozofię prawa do czegoś podobnego do nauk przyrodniczych (empirycznych); odpowiedź na pytanie o to, czy jest to zasadne, pozostawię już jednak na inną okazję. Niniejszy artykuł, jako że stanowi zreferowanie poglądów Karla Nickersona Llewellyna, będzie natomiast napisany zgodnie ze świadomie przyjętą przez tego filozofa konwencją .

${ }^{4}$ Tak np. współczesny przedstawiciel pragmatyzmu prawniczego Richard A. Posner pozwala sobie porównywać sędziów, którzy nie mają w danej kwestii prawnej ostatniego słowa [prawo przez nich stworzone może być później łatwo uchylone przez legislaturę], do psa szczekającego bardziej zażarcie, bo jest za płotem; w odniesieniu z kolei do wyróżniania precedensów sądowych „aż do śmierci” (ang. distinguishing to death) przywołuje twierdzenia o gotowaniu żaby (tj. ażeby ugotować żabę, należy włożyć ją do gorącej wody i powoli zwiększać płomień - bo jakby się ją wrzuciło od razu do wrzątku, to by wyskoczyła i trzeba by ją było wtedy wkładać tam z powrotem i do tego jeszcze ją tym razem przytrzymywać). W kontekście zaś prawa konstytucyjnego i sposobu, w jaki sędziowie Sądu Najwyższego Stanów Zjednoczonych uzasadniają wydawane przez siebie na podstawie tego prawa wyroki, przytacza on następujący kawał: „Pobożny Żyd, przechodząc obok lokalu miejscowego mohela (osoby, która dokonuje rytualnego obrzezania) i widząc zegarki kieszonkowe wyłożone na wystawie, nie kryjąc swojego zaskoczenia, wchodzi i mówi: «Mohel dlaczego ty wystawiasz zegarki kieszonkowe w twoim oknie [sklepowym]?» Na co ten mu odpowiada: «A co chciałbyś żebym [tam] wystawiał?»”. Zob. odpowiednio R. A. Posner, How Judges Think, Harvard University Press, Cambridge 2008, s. 353, 277 oraz przypis 5 na s. $350-351$.

Również niektórzy anglosascy sędziowie nie przebierają w słowach, gdy tylko chcą przekazać nam jakąś cenną w ich mniemaniu myśl. Tak np. sędzia Sądu Najwyższego Australii, L. Murphy, miał sugerować, iż rygorystyczne przestrzeganie precedensów to ,postawa nadzwyczaj adekwatna dla nacji w przeważającej mierze składającej się z owiec”, a Lord Radcliffe twierdzić, że ,jeśli sędzia o rozsądnie mocnym umyśle uważa jakiś precedens za zły, to musi być wielkim głupcem, jeśli nie potrafi go obejść". Zob. odpowiednio: M. Kirby, Precedent-Report On Australia, wygłoszone na International Academy of Comparative Law Conference, Utrecht, 17 lipca 2006, www.hcourt. gov.au/assets/publications/speeches/former-justices/kirbyj/kirbyj_17jul06.pdf (dostęp: 6.12.2015), s. 2 oraz S. Hanson, Legal Method \& Reasoning, wyd. 2, Cavendish Publishing Limited, London 2003, s. 73.

${ }^{5} \mathrm{O}$ tym, że Llewellyn nie dba o to, co uchodzi za stosowne [w przypadku tekstów ukazujących się drukiem], a tym bardziej jeszcze o samą „manierę”, gdyby tylko miałby ucierpieć na tym przekaz, jaki kierowany jest tu do studentów, wprost dowiadujemy się już z przedmowy i to zarówno do pierwszego, jak i do drugiego wydania The Bramble Bush'a. 


\section{LLEWELLYNOWSKI ATAK NA PRAWNIKÓW}

„I jak zakładam pierwsza i wyróżniająca się rzecz to to, że prawnik jest nie-

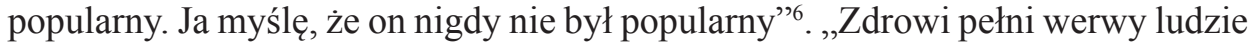
z wielu pokoleń podnosili swoje pałki, by strzaskać nimi czaszki prawników"7. Przy tym taka niepopularność wydaje się dla Karla Nickersona Llewellyna tak naturalna jak wąsy u kota ${ }^{8}$, a jej przyczyny mają być w jego ocenie różnorakie.

Przede wszystkim - jak wyjaśnia nam autor The Bramble Bush'a - prawnik jest specjalistą, pracującym w zawodzie zbyt skomplikowanym, by łatwo go można było zrozumieć. Każdy zaś taki specjalista, każdy taki „mistrz tajemnicy” jest podejrzany dla ignoranta. Nie, on jest podejrzany dla innych specjalistów; w myśl zasady: „Im bardziej wysoko wyspecjalizowana, delikatna, dziwna jest czyjaś praca, im więcej musimy korzystać z tego kogoś usług, tym mniej go kochamy"'.

Przy tym w ocenie Llewellyna praca prawnika ma być gorsza od pracy lekarza, którego sekretne rzemiosło polega na zwalczaniu natury. Lekarz wraz ze wzrostem jego wiedzy i przy odrobinie szczęścia może bowiem zwiększać odsetek skuteczności swoich lekarstw. A prawnik - nie. Pięćdziesiąt procent spraw, z jakimi się do niego przychodzi, jest bowiem przegrana - i musi być przegrana, tak długo jak prawo jest tym, czym jest ${ }^{10}$.

Ponadto zawód prawnika - jak kontynuuje Llewellyn - to taki niewdzięczny biznes, w którym jest się rzecznikiem kogoś, kto może odnieść zwycięstwo tylko wtedy, gdy zdepcze drugiego. Mało dziwi więc, że zdeptany nie będzie lubił prawnika. Ale również nie lubi go ten, kto wygrał sprawę. Klienci prawnika nie rozumieją, co on dla nich zrobił ani tego, jak on to zrobił. Patrząc z ich perspektywy, prawnicy wydają się przedstawiać „,wyższą sprawę” w kategoriach jakichś błahych trików. Klienci ci nie mogą zrozumieć labiryntu formalności. Procedura sądowa jest ślepa, beznadziejna i odrażająca dla laika. Ale to nie technika sprawia, że laikowi robi się tutaj niedobrze ${ }^{11}$. Jak mówi Llewellyn: „Triki jego własnego zawodu on przyjmuje z rozkoszą; triki na boisku on docenia i wielbi; ale triki, których nie potrafi pojąć - o to już co innego. On [laik] widzi sprawę, w jakiej ma swój interes, [ale] nie widzi powodu, dlaczego techniczna zręczność miałaby stać pomiędzy nim a jego zwycięstwem. I kiedy jest [już nawet] zwycięzcą, ma mało szacunku do tego, kto wygrał przez wypuszczenie jedwabistych sznurków przed kostki innego gościa i przez zaciśnięcie jedwabistych węztów wokót innego gościa szyi" ${ }^{12}$.

${ }^{6}$ K. N. Llewellyn, The Bramble Bush. The Classic Lectures on the Law and Law School. With a New Introduction and Notes by Steve Sheppard, Oxford University Press, New York 2008, s. 155.

7 Ibidem.

${ }^{8}$ Ibidem, s. 160.

9 Ibidem, s. 157.

${ }^{10}$ Ibidem.

${ }^{11}$ Ibidem, s. 157-159.

12 Ibidem, s. 159 (kursywa dodana). 
Tak więc - w ocenie Llewellyna - są trzy zasadnicze powody nielubienia prawnika: a) on praktykuje czarną magie, b) jest kuglarzem (stosuje triki) i c) połowa tych, którzy się do niego udają, jest „utopiona”"13.

Do tych trzech autor The Bramble Bush'a dodaje jeszcze jedną, a w zasadzie dwie dalsze przyczyny. Mianowicie, według niego prawo ma być zorganizowane w kategoriach tego samego porządku, jaki na chwilę przestał funkcjonować, i prawo ten też porządek chroni, ilekroć tylko się on rozpada. Stąd również prawnicy, gdy bronią prawa, bronią jednocześnie zastanego porządku, który na tę chwilę może być już przestarzały, a w tym uciskać słabych, bezradnych i nieszczęsnych. Prawnicy występują przeciwko roszczeniom, jakie są nowe i jakie mogą być humanitarne oraz atrakcyjne (jak cytuje tu Llewellyn Nowy Testament: „Biada wam również, wy prawnicy, bo wy obarczacie ludzi ciężarami niezmiernie trudnymi do zniesienia, a sami nie dotykacie ich nawet jednym palcem"). Podstawowym atrybutem prawa jest bowiem - jak twierdzi Llewellyn - konserwować, zawekować nowe okoliczności w starych pudłach (i to niezależnie od tego, czy te pudła pasują czy nie), nie zmieniać, nie dostosowywać, nie leczyć. To nie dotyczy co prawda każdego prawa i prawnika, bo czasem prawnicy są liderami reformy i prawo staje się instrumentem zmiany. Ale nawet wówczas przed każdą taką zmianą ma być długotrwała walka i ma być cierpienie: „cielsko prawa, rzędy prawników stoją w zamkniętych zbrojach przeciwko zbliżającej się zmianie". Gdy zaś ta zmiana już nadchodzi, gorzkość zostaje, bo zmiana ta jest o wiele spóźniona ${ }^{14}$.

$\mathrm{Z}$ podobnych względów - zdaniem Llewellyna - najzdolniejsi prawnicy mają też występować po stronie „posiadaczy”, a nie po stronie tych, którzy „nie mają" (do tego muszą oni mieć przy tym „odporne” sumienie i być pozbawionymi uczuć). Przy tym nie da się żyć z „posiadaczami”, nie zaraziwszy się od nich. Najlepsze talenty palestry zawsze będą się gromadzić, by zatrzymać wewnątrz tych, co są wewnątrz, i stać na barykadzie przeciwko tym, co są na zewnątrz. I jak w teorii prawo jest równe dla wszystkich, tak lepszy człowiek, bardziej umiejętny, bogatszy, ten, który może nająć lepszych, zdolniejszych prawników, będzie miał tu w praktyce przewagę ${ }^{15}$.

Należy zauważyć, iż wszystkie powyższe powody braku popularności prawników wydają się aktualne po dzień dzisiejszy. Polski dotyczy najbardziej chyba ostatni z omawianych. Aczkolwiek, biorący się z niskiej świadomości prawnej, brak rozumienia aspektów pracy prawnika i jego warsztatu u przeciętnego członka społeczeństwa, a także brak wdzięczności po stronie klienta wygrywającego proces także wydają się w odniesieniu do Polski istotne. Jeśli chodzi o to ostatnie, to do powyższych - jakże celnych - wywodów K. N. LLewllyna można by dodać jeszcze jakieś dziwne uwarunkowanie psychologicznie. Przed zakończeniem

\footnotetext{
13 Ibidem, s. 159.

${ }^{14}$ Ibidem.

${ }^{15}$ Ibidem, s. 160.
} 
procesu, w jego trakcie, osoba zwracająca się o pomoc do prawnika obawia się, że sprawę przegra i jest wdzięczna, że ktoś inny zajmuje się jej interesami, że ktoś jej pomaga. Ale już po dowiedzeniu się o wygranej, może nie od razu (nie w pierwszym przypływie chwili), lecz krótko po tym, ta jej wdzięczność jakoś blaknie, jeśli nie całkowicie zanika. Tak jakby z góry było wiadome, że wygra ona daną sprawę, jakby ta jej wygrana brała się bezpośrednio z obowiązującego prawa, nie będąc w żadnej mierze zasługą prawnika, z którego usług przyszło jej korzystać. Momentalnie prawnik ten schodzi tu na plan dalszy, jeśli nie zupełnie znika: jeżeli już bowiem komukolwiek, to wygraną należy zawdzięczać nie temu prawnikowi, lecz dobroduszności orzekającego sędziego. Być może takie przeświadczenie u klienta prawnika bierze się właśnie z tego, iż jak mówił Llewellyn, laik nie może pojąć, a przez to i trudno jest mu docenić wielkość stosowanych przez prawników trików. Wydaje się jednak, że jest tu coś jeszcze.

\section{LLEWELLYNOWSKA OBRONA PRAWNIKÓW}

Llewellyn nie byłby jednak sobą, gdyby nie podjął się obrony prawniczej profesji i zbijania jeden po drugim wysuniętych powyżej zarzutów. Profesji prawników - jego zdaniem - zarzuca się bowiem to, co wiele profesji powinno „w nadziei” chcieć osiągnąć, tj. tak wysoki stopień specjalizacji, iż ta jawi się jako rodzaj swoistej własnej czarnej magii (black art of its own). To wszystko mianowicie, co sprawia, że prawo jawi się jako groteskowe lub podejrzane, bierze się - w opinii Llewellyna - stąd, iż przeciętnemu człowiekowi wydaje się, że on sam posiada wystarczającą wiedzę, by poprzez swój zdrowy rozsądek wyrokować, co jest sprawiedliwe, a co nie. W konsekwencji to, co robią prawnicy, musi mieć coś wspólnego z diabolicznymi praktykami. Przeciętny człowiek nie przypisuje też takiej wiedzy [jaką posiadają prawnicy] inżynierii, którym to też sposobem rzemiosło inżynierów jest bardziej białą aniżeli czarną magią ${ }^{16}$.

Z kolei odnośnie do procedury (trików i technikalności) to oskarżenia w tym zakresie ma być łatwo odeprzeć. Ta procedura nie czyni bowiem prawników ani niekompetentnymi, ani nie jest przejawem „nieustępliwego rytualizmu”. To znaczy, że pozwala ona realizować zarówno interesy klientów, jak i pamiętać - o ile te tu są - o względach sprawiedliwości ${ }^{17}$.

W przedmiocie natomiast zarzutu o maglowanie regułami, aby wygrać, o to, że w prawie nie uzyska się korzyści inaczej niż poprzez zdeptanie drugiego, położenie buta na przegranym, tego, że grubszy portfel zapewnia niesłuszną przewagę, że prawo sprzyja zastanemu porządkowi również wtedy, gdy ten wcale nie jest

\footnotetext{
16 Ibidem.

17 Ibidem.
} 
najlepszy, Llewellyn twierdzi, iż prawo i prawnicy (ich profesja) nie wyróżniają się tu wcale. W tym względzie stanowią oni bowiem niewypaczone odzwierciedlenie społeczności, która próbuje im coś zarzucać. To klienci prawników, a nie oni sami, są tymi, którzy chcą wygrać i ,sprać” innych ludzi. To też przecież nie prawnicy są odpowiedzialni za kolidujące ze sobą grupy interesów. To również nie prawnicy, lecz społeczeństwo, daje w walce przewagę lepiej usytuowanym i ,przypiera" na korzyść tych, co są wewnątrz. W rezultacie 3/4 brudu ma być tu zassane, aczkolwiek reszta nie. Ale - jak pyta Llewellyn - czy powinniśmy zaprzeczać temu, że jak się miesza mądrość zawodową z czystą smołą życia, to część tej smoły się przyklei. Przy tym Llewellyn osobiście nie ma mieć zbyt wiele cierpliwości względem człowieka, który oskarża drugiego za to, że ten wykonuje za niego czarną robotę ${ }^{18}$.

Co więcej, w opinii Llewellyna prawnikom zawdzięcza się osiągnięcia, które - przynajmniej w jakimś stopniu - równoważą ich wady. Co by bowiem nie mówić, to nikt inny jak właśnie prawnicy, poprzez swoją ciężką pracę, dostosowują stare, utykające, kulejące, brzdękające prawo do nowych potrzeb, wymyślając nowe instytucje prawne. Nawet gdy to nie prawnik jest tym, od którego najpierw wyszedł dany pomysł, to i tak pozostaje on cennym społecznym inżynierem. To on dostrzega nowo powstałą potrzebę i to on szuka sposobu, by na tę potrzebę odpowiedzieć; wymyśliwszy tak hipotekę, konosament, weksel, wieczystą dzierżawę czy spółki. Ponadto osiągnięcia w prawie mają być - zdaniem Llewellyna - zbyt łatwo przypisywane sędziom. Tymczasem to prawnicy [w znaczeniu pełnomocnicy procesowi] podsuwają sędziom innowacyjne rozwiązania, a ci je często tylko aprobują.

Przy tym, puentując, Llewellyn trawestuje tu słowa wiersza Carla Sandburga The Lawyers Know too Much, iż to piosenkarze, którzy śpiewają i marzyciele, którzy układają sztuki - choć są nimi w tym przypadku prawnicy - budują dom,

\section{którego żaden wiatr nie zdmuchnie ${ }^{19}$.}

Ogólnie w tak przeprowadzonej obronie prawniczej profesji trudno coś dodać lub ująć. Jej argumenty wydają się trafne i mocne, a ona sama - wyważona; choć trzeba przyznać, iż nieco cyniczna lub jak kto woli - „realistyczna”. Chcąc przenieść ją jednak na grunt polski, należy nadmienić, iż mówiąc o osiągnięciach, jakie społeczeństwo zawdzięcza prawnikom, na których zwykło ono narzekać, Llewellyn miał na myśli system prawny typu common law. System ten charakteryzuje się tzw. case law, a więc prawem, jakie budowane jest w oparciu o zasadę związania precedensem sądowym (zwaną z łaciny: stare decisis) i jakie daje sędziom faktyczną możliwość oficjalnego lub quasi-oficjalnego stanowienia pra$\mathrm{wa}^{20}$. W przypadku systemu prawnego typu civil law (występuje w Polsce i innych

${ }^{18}$ Ibidem, s. 160-161.

19 Ibidem, s. 161-163.

${ }^{20}$ Odnośnie do sposobu działania zasady stare decisis oraz innych instytucji prawnych związanych z tą zasadą, zob. M. Koszowski, Anglosaska doktryna precedensu. Porównanie z polska praktyka orzecznicza, Warszawska Firma Wydawnicza, Warszawa 2009. 
państwach Europy kontynentalnej z wyjątkiem Skandynawii) pole do podsuwania sędziom przez pełnomocników procesowych nowych instytucji prawnych i przyczyniania się w ten sposób do postępu społecznego i gospodarczego wydaje się raczej nikłe. Tu architektem prawa są bowiem głównie demokratycznie wybrane ciała (parlamenty), ewentualnie instytucje Unii Europejskiej lub organy władzy wykonawczej, a nie jak w przypadku anglosaskiego common law - mający cieszyć się z tego powodu szczególnym poważaniem w społeczeństwie - orzekający w sądach wyższej instancji sędziowie ${ }^{21}$. Ergo, jeśli chodzi o polskich prawników, ten argument Llewellyna odpada. Pozostałe pozostają jednak w pełnej mocy.

\section{KWESTIA ETYKI I ODPOWIEDZIALNOŚCI}

Co ciekawe, zwieńczeniem powyższych rozważań jest poruszenie kwestii odpowiedzialności, jaka występuje po stronie prawnika, odpowiedzialności, która wykracza poza jego klienta, która wychodzi poza jego otoczenie, która sięga do przyszłości ludzkości. Od tej odpowiedzialności wobec własnego gatunku ma nie być przy tym - zdaniem autora the Bramble Bush'a - ucieczki. Samo to, że laik nie wie o tym, że na prawniku spoczywa taka odpowiedzialność i nie dba o tę odpowiedzialność, bynajmniej nie czyni ucieczki od niej możliwym. Odpowiedzialność, o jakiej tu mowa, polega bowiem na wyborach prawnika i tylko jego. On, prawnik, może zarówno przyczyniać się do postępu, jak i blokować drogą „najgenialniejszej pomysłowości” każdy krok naprzód. Ale w tym samym czasie on musi przeżyć, on musi zapłacić czynsz; a mieć dochód i stawić czoła odpowiedzialności to zdaniem Llewellyna trudny tandem do jazdy ${ }^{22}$.

W tym miejscu Llewellyn przytacza też dwie fundamentalne zasady natury etycznej, które mają pomóc prawnikom w tej jeździe. Pierwszą z nich - poważaną jak mało co i to nie tylko przez prawniczą profesję, ale i społeczeństwo - jest to, iż prawnik powinien wierzyć w sprawę [jej słuszność], której obrony się podejmuje. Jak bowiem wierzy on w taką sprawę, to - zdaniem Llewellyna - będzie on w niej walczył bardziej zażarcie, będzie myślał bardziej umiejętnie, całe jego jestestwo zostanie uwolnione takim jego przeświadczeniem. Od tego zaś między innymi zależy sukces w tej sprawie: kiedy prawnik stanie się symbolem swojej sprawy i zyska respekt przed ławą przysięgłych, kiedy położy na nią swoją reputację ${ }^{23}$. Ludzie z uśmiechem (drwiną) mówią jednak o typowym temperamencie

${ }^{21}$ Zob. R. Cross, Precedent in English Law, wyd. 2, The Clarendon Press, Oxford 1968, s. 13; R. Cross, J. W. Harris, Precedent in English Law, wyd. 4, Oxford University Press, Oxford 1991, s. 13.

${ }^{22}$ K. N. Llewellyn, op. cit., s. 163.

${ }^{23}$ Ibidem. 
adwokatów i śmieją się czy też drwią, obserwując szybkość, z jaką większość prawników zyskuje wiarę w sprawę, z którą zgłasza się do nich klient. Co więcej, chcąc zapłacić czynsz, dzisiejsi prawnicy stają się osobami identyfikującymi się z ich klientami lub konkretnymi interesami, stając się „bankowymi prawnikami”, „kolejowymi prawnikami”, „cukrowymi prawnikami”. Wówczas też, w takiej zależności, oni powinni oczywiście odrzucić te sprawy, w które nie wierzą. Tymi zaś są, jak można zaobserwować, te, które są wymierzone przeciwko bankom, cukrowniom, kolejom... ${ }^{24}$.

Ta zasada, wiary w daną sprawę, ma być też - w ocenie Llewellyna - szczególnie przydatna, gdy dostrzega się, że sprawa biednego człowieka nie jest warta takiej wiary. Jeśli natomiast przychodzi ktoś z niezłym brzuszkiem, jego portfel może być gruby, ale jego sprawa wygląda marnie, to wtedy co? Wtedy - mówi Llewellyn - odwagi moi przyjaciele! Wtedy mamy drugą zasadę; uwielbianą zasadę, w świetle której jest jasne, iż prawnik nie jest ani sędzią, ani ławą przysięgłych. Prawnik nie ma ani obowiązku, ani prawa, by uzurpować sobie funkcje sądowe. To nie jego rzecz, by skazywać człowieka zanim zapadnie werdykt ławy przysięgłych. Esencją sprawiedliwości jest to, by każdy miał uczciwy proces, miał żarliwą obronę przed sądem, miał zapewniony uczciwy proces. Identyfikowanie prawnika ze sprawą [jej słusznością] to zaprzeczenie prawa do uczciwego procesu. I to ma być druga, najbardziej zresztą poważana wśród członków prawniczej profesji, zasada etyczna ${ }^{25}$.

Przy tym Llewellyn twierdzi, że zarzut, iż te dwie zasady pozostają ze sobą w sprzeczności, iż ktoś nie może całkowicie wierzyć w sprawę [jej słuszność], jakiej obrony się podejmuje, i jednocześnie przyczyniać się do realizacji zasady uczciwego procesu w sprawie, w którą on nie wierzy, jest naiwny. Prawo jest bowiem elastyczne i w wielu miejscach wątpliwe. Reguły „nie kontrolują” konkretnych spraw, a precedens sądowy zawsze można interpretować raz węziej, raz szerzej (spiłować go do grubości brzytwy lub rozciągnąć go do wielkości maczugi). Skoro zaś tak, to - jak przewrotnie pyta się Llewellyn - dlaczego etyka gry miałaby być inna od tego, jaka jest sama gra: owszem z jednej strony te dwie zasady są sprzeczne, ale równocześnie każda z nich jest prawdziwa, rozsądna, wykonalna. To z kolei, której i kiedy użyć, zależy już od każdego prawnika indywidualnie. Szukanie odpowiedzi na zewnątrz ma być daremne. Zdaniem Llewellyna nie ma bowiem żadnych reguł, które wzięłyby na siebie odpowiedzialność za ten wybór ${ }^{26}$.

Dalej autor the Bramble Bush'a konstatuje, że jak znajdzie się jakiegoś klienta, to, by zapewnić sobie sukces, należy obrać dogodną etykę w dogodnym czasie. To znaczy, że należy podkreślać zasadę uczciwego procesu, jak sprawa grubego klienta wygląda źle (chyba że szczęśliwym trafem wierzy się w sprawę takiego

\footnotetext{
${ }^{24}$ Ibidem, s. $163-164$.

${ }^{25}$ Ibidem, s. 164-165.

${ }^{26}$ Ibidem, s. 165.
} 
klienta), albo podkreślać to, że konieczna jest wiara w sprawę, której obrony się podejmuje, ilekroć nie chce się uwierzyć w sprawę wygłodzonego, wynędzniałego kolesia. Cokolwiek się tu zrobi (wybierze), będzie uszanowane: „ludzie będą was podziwiać, będziecie spać po nocach spokojnie, a wasze sumienie będzie czyste, wasz podatek od zysku będzie rósł" ${ }^{27}$.

Chyba po to, żeby jeszcze bardziej podnieść napięcie, Llewellyn podpowiada tu też przyszłym adeptom prawa, iż za swój totem, swój ideał mogą obrać kałamarnicę, mątwę. Kręgosłupa ona nie ma, ale dziób, o to ona ma. Kręgosłup jest nieobecny, ale dziób jest mocny. Ma dziesięć nóg, każda ruchliwa z przyssawką, każda wachluje wodę w poszukiwaniu ofiary. Dla pełnej jasności Llewellyn podkreśla również to, iż on wcale nie jest w swych wywodach ironiczny ani cyniczny, lecz mówi na poważnie ${ }^{28}$. Owszem - jak tłumaczy się po tym stwierdzeniu autor the Bramble Bush'a - brak popularności prawniczej profesji, oskarżenia pod jej adresem nie mogą nam przysłaniać jej wyższej służby. To prawnicy, nie kto inny, dźwigają ciężar uczynienia tego, by warto było mieć prawo. I on, Llewellyn, dostrzega tu tę odpowiedzialność, ale widzi również łatwość, z jaką ta odpowiedzialność może być odstawiona na bok i to odstawiona w nieświadomości jej odstawienia. On widzi dobrze tę dwuznaczną etykę, widzi balsam i samozadowolenie, którymi etyka ta nęci bezkręgowce, jakie są wśród nas. Presja, by pozwolić osunąć się ciężarowi [odpowiedzialności], ma wkrótce zresztą przyjść do każdego. Zgodnie z tym, jak się rzeczy mają, ta presja jest też niemalże nie do odparcia. I jak wieszczy Llewellyn:

Będzie bardzo niewielu, którym oczu ona nie zamknie. Będzie bardzo niewielu, którzy podołają by dać jej opór. Ale za dwadzieścia lat od teraz [od momentu gdy wypowiada te słowa do uczestników studiów prawniczych], to sprawi [mu] wielką przyjemność, da głupią satysfakcję, będzie zaszczytem, by spotkać tych nielicznych i wziąć ich za rękę ${ }^{29}$.

Co warto zauważyć, dylemat, o jakim wspomina autor the Bramble Bush'a, jest nie tylko aktualny po dzień dzisiejszy, lecz jakby jeszcze bardziej wyrazisty i brzemienny. Od tego, prowadzenia jakich spraw podejmie się współczesny prawnik, a w przypadku jakich obrony odmówi, zależy kształt dzisiejszych stosunków społecznych, politycznych czy nawet gospodarczych. Prawnik ten może doradzać konsumentom, ale też i przedsiębiorcom, może chronić prawa obywateli, ale też i działać w imieniu i na zlecenie władzy, przyczyniać się do realizacji interesów najemców albo interesów wynajmujących, bronić w sądzie przestępców albo reprezentować pokrzywdzonych itd. W zależności od jego wyborów i żarliwości, z jaką będzie walczył o wygraną, inne będą wyroki i inni ludzie uzyskają wsparcie. Współczesny prawnik - czy chce tego, czy nie - jest społecznym inżynierem, czasem tylko na małą, ale czasem i na dużą skalę.

\footnotetext{
${ }^{27}$ Ibidem, s. 165-166.

${ }^{28}$ Ibidem, s. 166.

${ }^{29}$ Ibidem.
} 
Prima facie przepisy prawa obowiązującego w Polsce zdają się nie pozostawiać prawnikom w tej kwestii wyboru, ściągając - jak powiedziałby to Llewellyn - odpowiedzialność za taką inżynierię z ich barków. Przepisy te nakazują bowiem, zarówno adwokatom, jak i radcom prawnym, prowadzenie również tych spraw, w których słuszność ci nie wierzą, zupełnie rugując tak tę zasadę etyczną, która pozwalała, czy wręcz nakazywała, na odmowę podjęcia się w takim przypadku obrony ${ }^{30}$. W efekcie zgodnie z polskim prawem prawnik musi bronić oskarżonego, nawet jeśli wie, iż ten popełnił przestępstwo i jego czyn zasługuje na potępienie, tudzież zobligowany jest reprezentować oszusta podatkowego albo pracodawcę $\mathrm{w}$ sporze $\mathrm{z}$ pracownikiem, który nie otrzymał od tego pracodawcy należnego za pracę $\mathrm{w}$ godzinach nadliczbowych wynagrodzenia.

Tak jest jednak raczej tylko $w$ teorii. Nawet bowiem gdy dana sprawa jest ewidentnie słuszna, a do polskiego prawnika zgłasza się biedny człowiek (lub prawnik ten nie chce się przeciwstawiać interesom pozwanego), to prawnik ten zawsze może:

- powiedzieć, iż nie ma wystarczającej wiedzy, by mógł zająć się tą sprawą;

- zaproponować tak wysoką stawkę tytułem swojego wynagrodzenia, że klient sam zrezygnuje $\mathrm{z}$ jego usług;

- tak przedstawić - co wydaje się zresztą najbardziej nieetyczne - klientowi sprawę, z jaką ten do niego przyszedł, by przekonać go, iż sprawa ta jest tak beznadziejna, iż niewarta jakiejkolwiek obrony.

W ramach tej ostatniej opcji wyobrażalne jest też oczywiście sporządzenie, poprzez wykorzystanie wątpliwości w prawie, opinii o braku podstaw do wytoczenia powództwa (wniesienia apelacji/kasacji). Ewentualnie w Polsce prawnik, któremu nie podoba się sprawa, z jaką zgłosił się do niego klient, może prowadzić taką sprawę w taki sposób, z takim brakiem pośpiechu i zaangażowania, iż sprawa ta zostanie ostatecznie w sądzie przegrana, choć przy prowadzeniu jej w sposób bardziej żarliwy zwycięstwo w niej jawiło się jako bardzo prawdopodobne.

W konsekwencji można powiedzieć, iż kwestia odpowiedzialności, do jakiej nawiązał K. N. Llewellyn, mimo takiej a nie innej treści przepisów polskiego prawa $^{31}$, dotyczy również prawników działających w Polsce. Każdy z nich będzie

${ }^{30}$ Brak wiary w daną sprawę (jej słuszność) trudno byłoby uznać za „ważny powód”, do jakiego nawiązują art. 28 ust. 1 ustawy z dnia 26 maja 1982 r. prawo o adwokaturze (Dz. U. 1982, nr 16, poz. 124 z późn. zmianami) oraz art. 22 ust. 1 ustawy z dnia 6 lipca 1982 r. o radcach prawnych (Dz. U. 1982, nr 19, poz. 145 z późn. zmianami) i jaki na podstawie tych artykułów uzasadnia dokonanie odmowy udzielenia pomocy prawnej przez adwokata/radcę prawnego. Jeszcze trudniej byłoby zresztą utożsamiać brak takiej wiary z uzasadniającym odmowę podjęcia się prowadzenia danej sprawy konfliktem interesów.

${ }^{31}$ Zasadność niepozostawienia przez polskiego prawodawcę miejsca dla zasady, iż prawnik powinien się podejmować obrony spraw, w których słuszność wierzy, wydaje się też stać pod dużym znakiem zapytania. Jak bowiem tłumaczył to K. N. Llewellyn, od takiej przecież wiary w dużej mierze zależy sukces w danej sprawie. Abstrahując już od konfliktu z własnym sumieniem (chyba że polski prawodawca zakłada, iż prawnik nie ma sumienia), bez takiej wiary niejednemu może być trudno zaangażować się w dostatecznym stopniu w obronę sprawy, z jaką przyszedł do niego klient; 
musiał dokonywać indywidualnych wyborów, decydując o tym, jakim sprawom, i w jakim stopniu się poświęci, do jakich zwycięstwa będzie uparcie dążył, a szanse na zwycięstwo w jakich zmniejszy lub zaprzepaści. To też od niego będzie w dużej mierze zależało, czy sprawa biednego wynędzniałego człowieka wymierzona przeciwko wielkim korporacjom będzie tą, której trzeba się pozbyć, a podła sprawa zamożnego człowieka będzie tą, która zasługuje na uczciwy proces w myśl zasady: adwokat nie sędzia i sam niczego osądzać nie może.

\section{ODPOWIEDZIALNOŚĆ - CZĘŚĆ DALSZA}

Problem odpowiedzialności u prawników i pokusa wyzbycia się jej są też przedmiotem rozważań Llewellyna zamieszczonych w rozdziale pt. Beyond Bread and Butter. Tutaj autor the Bramble Bush'a wyjaśnia nam bowiem, iż zawód prawnika to nie tylko pieniądze - choć te czynią życie możliwym, są miarą sukcesu, prestiżu i władzy, są miarą człowieka. W tym kontekście najbardziej kłopocze jednak Llewellyna kwestia posiadania i wychowania potomstwa, na które by się chciało przenieść więcej nadziei i ambicji aniżeli na własną karierę. On widzieć miał bowiem córki i synów takich nastawionych tylko na zarabianie pieniędzy prawników, które to dzieci po tym, jak stały się już dorosłe, nie chcą być w żadnym razie jak ich rodzice. Wówczas też satysfakcja takich prawników z ich osiągnięć blednie, ustępując pozbawionej nadziei pustce. Stąd też osobiście radzi on przyszłym adeptom prawa, że jeśli to ma być ich cel w życiu, to lepiej niech się oni nie żenią. To znaczy, że wydaje się możliwe komfortowe bycie w takim układzie mężem, choć nie będzie to łatwe dla żony, ale bycie już ojcem wiąże się

w efekcie czego dla tego klienta o wiele lepiej byłoby, gdyby jego sprawą zają się ktoś inny, kto w jej słuszność rzeczywiście wierzy lub komu brak wiary w jej słuszność w zupełności nie przeszkadza. Wszak taki ktoś: „będzie walczył bardziej żarliwie, będzie myślał bardziej umiejętnie, uwolni w jej interesie całe swoje jestestwo".

Nie jest to jednak pierwszy i ostatni przykład lekceważenia przez polskiego prawodawcę aspektu psychologicznego, jaki towarzyszy wykonywaniu zawodu adwokata (radcy prawnego). Jako inny przypadek takiego lekceważenia można tu podać treść art. 162 k.p.c., zgodnie z którym, by móc powoływać się na uchybienia przepisom normującym procedurę cywilną, jakie miały miejsce w trakcie postępowania przed sądem, strona (jej pełnomocnik procesowy) musi - jeszcze przed wydaniem wyroku w jej sprawie - wnieść o wpisanie stosownego zastrzeżenia do protokołu. Wniesienie takiego zastrzeżenia, które trudno uważać tu za coś innego niż skargę na orzekającego sędziego, będzie jednak musiało - choćby nieświadomie - nieprzychylnie nastawiać tego sędziego do tego, kto wytyka mu błędy. Tym samym tam, gdzie jest to możliwe, powinno się dążyć to tego, by skargi na sędziego miały miejsce dopiero po tym, jak podejmie on decyzję dotyczącą interesów skarżącego (takie lub podobne założenie wydaje się też stać za wymogiem rozpoznania sprawy przekazanej, przez sąd drugiej instancji, sądowi pierwszej instancji do ponownego rozpoznania przez inny niż poprzednio skład orzekający - art. $386 \S 5$ k.p.c.). 
z posiadaniem ludzkich wartości, które będą przy takim wyborze zawadzać [Llewellyn zwracał się w swych wykładach tylko do płci męskiej, nie dlatego jednak, jak się wydaje, że był seksistą, tylko dlatego, że studentek prawa w jego czasach niemalże wcale nie było - M. K.].

W mniemaniu Llewellyna mają być jednak ludzie, którym w nastawieniu się tylko na robienie pieniędzy stoi na przeszkodzie zażarty, niespokojny temperament. Oni tworzą inny trend w palestrze. Mają ideały innego sortu. Tak jak akademicy padli ofiarą tego dziwnego uczucia, iż zawód (profesja) ma pewne zobowiązania wobec społeczności, której służy (bądź twierdzi, że służy). Po pewnej chwili autor the Bramble Bush'a dodaje również, że ci prawnicy nie są jak inni; oni nie topią się jak tamci w profesji; oni - z tej właśnie przyczyny - często tych innych przerastają. Oni przewyższają „prawniczych szewców” (the legal cobblers), ale też i „sprzedają” (outsell) więcej niż oni. Innym jeszcze powodem ich sukcesu jest - zdaniem Llewellyna - to, że mają mózgi i są gorliwi. Obserwując, jak wygląda życie, wiedzą, iż droga do pieniędzy to droga do wolności. To wolność bowiem jest ich pragnieniem ${ }^{32}$.

W efekcie Llewellyn w swoim ironicznym stylu radzi:

Jeśli natura jest nieuchronna i jesteśmy z tego powodu poniewierani. Idźcie zatem chłodni i zdeterminowani jednym celem w życiu. Jeśli bowiem jesteśmy poniewierani, ponieważ życie to ucieczka, i prawo to ucieczka, i ideały umiarkowanego sortu to szaleństwo, determinacja za rachunkiem bankowym będzie w porządku, i Boże pomóż każdemu, kto jest na tej drodze. Ja widzę ten efekt u wielu, i bije się w pierś za to, że przysłużyłem się do trenowania wilków ${ }^{33}$.

W jakiś czas po tym jeszcze dopowiada:

Róbcie co chcecie, przyjdzie rozczarowanie. Ale spójrzcie [wtedy - M. K.] ponownie, i zobaczcie moc życia, wigor, bujność życia trwającego chwalebnie - podczas oczekiwania niczego. Tu jest odpowiedź do naszej deziluzji, w tej starej prawdzie [irlandzkiej legendzie - M. K.], że ani tęcza, ani mający znajdować się na jej końcu dzban złota, nie dają się zdobyć, nie byłyby one zresztą warte posiadania, gdyby były osiągalne. Ale poszukiwanie jest dobre ${ }^{34}$.

Przy tym w deziluzji Llewellyn nie widzi bynajmniej stępienia zainteresowania. Raczej na jej skutek wszystkie zainteresowania mają stawać się większe i głębsze. Wszystko, co w jej wyniku zostało stracone, to bowiem oczekiwanie tego, co nieosiągalne. Przez to też to, co osiągalne, staje się więcej warte, bardziej fascynujące. Dwie rzeczy i tylko dwie rzeczy są tu potrzebne: chęć zrozumienia i pewna doza cierpliwości ${ }^{35}$. Pozbawieni iluzji mają mieć również trzy drogi do obrania, o ile nie chcą się oni roztrzaskać na kawałki. Pierwsza to całkowity

\footnotetext{
${ }^{32}$ K. N. Llewellyn, op. cit., s. 129-131.

33 Ibidem, s. 137.

${ }^{34}$ Ibidem, s. 138.

${ }^{35}$ Ibidem.
} 
egoizm w jakiejkolwiek postaci: samolubstwo, samo-bezsprzeczność, zamknięcie się w sobie. Druga to mistycyzm, który poprzez zwrócenie się do prawa, zostaje zdaniem Llewellyna niemalże zanegowany. Trzecia to wiara w wartościowość czynienia, przy akceptacji z góry tego, że nie uda się osiągnąć ostatecznego celu ${ }^{36}$. Taką zaś wiarę w wartościowość czynienia jako takiego i jej podłoże Llewellyn wyobraża sobie tylko w kategoriach zainteresowania ludźmi, Człowiekiem; co w przypadku prawników oznaczać ma przeszczepienie tego zainteresowania na prawo, wypracowanie jedności między prawem a przeżywaniem życia przez prawnika ${ }^{37}$.

Jak łatwo zauważyć, o ile wywody na temat przyczyn braku popularności prawników i dwóch podstawowych zasad etycznych, jakie tych prawników dotyczą, pozostają dość jasne i dobrze uargumentowane, przedstawione w kilku powyższych akapitach dywagacje są już o wiele mniej klarowne. W zasadzie do końca nie wiadomo, co autor the Bramble Bush'a chciał tu przyszłym absolwentom prawa przekazać. Nie miał on bowiem na myśli prostego zalecenia, iż należy się cieszyć chwilą. Bardziej chodziło mu o ukazanie jakiejś filozoficznej perspektywy, zakładającej być może jakąś szczególną ontologię. Choć ciśnie się tu na myśl ludowe porzekadło, iż „każdy filozof coś jakby bredził”, trzeba jednak zaznaczyć, iż Llewellyn wyraźnie widzi w prawnikach coś więcej aniżeli narzędzie do wygrywania cudzych sporów, ich ,prawdziwy” ideał stanowi u niego element jakiejś większej całości wizji, która ma własną misję i cele, jakie wychodzą poza partykularne interesy poszczególnych członków danej społeczności czy profesji ${ }^{38}$. Że też człowiek ten był i pewnie nadal będzie posądzany o wyzucie prawa i prawników z moralności, porzucenie ideałów sprawiedliwości itp. ${ }^{39}$

\section{PODSUMOWANIE}

Podsumowując, wypada zauważyć, iż Karl Nickerson Llewellyn podał bezpardonowy opis powodów tego, dlaczego prawnicy są w społeczeństwie nielubiani oraz stanowią często obiekt oskarżeń i utyskiwań ze strony przeciętnych obywateli. Niejako jednak jednocześnie przeprowadził on tychże prawników niemalże apoteozę. Przy tym nie tylko zbił wszystkie wysunięte pod ich adresem

${ }^{36}$ Ibidem.

37 Ibidem.

${ }^{38}$ Być może przydatna okaże się w tym kontekście jego własna uwaga poczyniona na temat czytania, tj. iż był czas, kiedy ludzie wkładali całych siebie (w tym swoje doświadczenia) w to, co czytali; dzisiaj natomiast autorzy wyręczają czytelnika w myśleniu - w sensie, iż każda myśl jest w całości rozciągnięta i powtórzona dwa razy; zob. ibidem, s. 138-139.

${ }^{39}$ Odnośnie do skarżenia się przez Llewellyna na tego rodzaju zarzuty i udzielonej przez niego na nie odpowiedzi zob. ibidem, s. XXVIII-XXX. 
zarzuty, lecz także dowiódł, że to społeczeństwo jest w znacznej mierze winne temu, jacy prawnicy są na co dzień. Co więcej, to jemu można wytykać, że nie potrafi ono docenić tego, co tak naprawdę zawdzięcza prawnikom.

Znamienne jest, że zarówno Llewellynowski atak na prawników, jak i ich Llewellynowska obrona pozostają w znacznej mierze aktualne i nad wyraz przekonywające po dzień dzisiejszy, co tylko świadczy o geniuszu autora the Bramble Bush'a.

Ciekawe jest także spojrzenie Llewellyna na kwestie odpowiedzialności, jaka - czy tego oni chcą, czy nie - spoczywa na osobach wykonujących zawód pełnomocnika procesowego, wraz ze stwierdzeniem, iż to od samych tych osób, a nie jakichś odgórnie narzuconych im reguł, zależy, jakich wyborów będą w swojej pracy dokonywać: czy będą nieść ludziom sprawiedliwość i postęp, czy też udaremniać swoją pomysłowością wszelkie zabiegi podejmowane w tym kierunku. Niezmiernie cenne są tu także wywody Llewellyna na temat etyki prawniczej. Poza tym, że są one pełne wysublimowanego sarkazmu i krytycznej ironii, jednocześnie zdają się odzwierciedlać to, jaka jest nie teoria, ale szara rzeczywistość. Wywody te zmuszają do głębszej refleksji nad rolą prawnika w społeczeństwie i nad tym, czego realnie można, a czego nie można od niego oczekiwać. Obecna w nich jest też cicha nadzieja - na zasadzie wiary w wielkość i doskonałość człowieka, choć ten musi sprostać warunkom, w jakich przyszło mu żyć i funkcjonować - na to, że prawnicy będą w swojej pracy bardziej etyczni czy wręcz bardziej moralnie doskonali.

Na powyższym tle rażą wszelkie już poczynione oraz potencjalne mogące zostać wysunięte pod adresem Llewellyna zarzuty jako człowieka pełnego cynizmu tudzież wysławiającego brutalną przemoc, arbitralność i niczym nieskrępowaną tyranię ${ }^{40}$. Zarzuty te, jak się wydaje, podyktowane są brakiem dostatecznej - czy wręcz jakiejkolwiek, poza poprzestaniem na zdaniu, że prawem jest to, co robią sędziowie - analizy jego poglądów. Co by bowiem o Llewellynie nie mówić, był on człowiekiem, któremu nieobojętna była przyszłość ludzkości i kształcenie odznaczających się wysokimi standardami etycznymi prawników. Bynajmniej nie zależało mu na wypuszczeniu na rynek prawniczy osób nieposiadających jakiejś szerszej perspektywy i niewierzących w głębsze wartości, a tym bardziej jeszcze - na wypuszczeniu na ten rynek pozbawionych uczuć, bezdusznych maszynek do zarabiania pieniędzy. 


\title{
BIBLIOGRAFIA
}

Cross Rupert, Harris James W. 1991. Precedent in English Law. Oxford: Oxford University Press. Cross Rupert. 1968. Precedent in English Law. Oxford: The Clarendon Press.

Hanson Sharon. 2003. Legal Method \& Reasoning. London: Cavendish Publishing Limited.

Holmes Oliver Wendell. 1965. „The Path of the Law”. Boston University Law Review 45: 24-42.

Hutcheson Joseph. 1998. „The Judgment Intuitive: The Function of the "Hunch” in Judicial Decision”. South Texas Law Review 39: 889-903.

Kirby Michael. 2006. Precedent - Report On Australia, wygłoszone na International Academy of Comparative Law Conference w: Utrecht, dn. 17 lipca 2006.

Koszowski Maciej. 2009. Anglosaska doktryna precedensu. Porównanie z polska praktyka orzecznicza. Warszawa: Warszawska Firma Wydawnicza.

Llewellyn Karl. 2008. The Bramble Bush. The Classic Lectures on the Law and Law School. With a New Introduction and Notes by Steve Sheppard. New York: Oxford University Press.

Posner Richard. 2008. How Judges Think. Cambridge: Harvard University Press.

\section{Maciej Koszowski}

\section{THE ROLE AND ETHICS OF THE LAWYER AS PERCEIVED BY KARL NICKERSON LLEWELLYN}

\begin{abstract}
Apart from a short introduction to the movement known as American Legal Realism, this paper describes the role and ethics of the lawyer as viewed by Karl Nickerson Llewellyn. The author invokes some of Llewellyn's outlooks and comments upon them, revealing their timeless character and highlighting the pertinent Polish peculiarities. Some of these peculiarities may seem slightly astonishing, particularly the lack in Poland of the ethical principle which prescribes that a lawyer should believe in his or her client's case. According to Polish law, the principle that everyone should be assured a fair trial (hearing) appears to be second to none and someone's conscience is no argument against denying the defense of a case that seems unworthy of being won.
\end{abstract}

Key words: legal ethics, legal realism, common law. 